\title{
Ankyrin Repeat and Kinase Domain Containing 1 Gene, and Addiction Vulnerability
}

\author{
Alejandra Koeneke ${ }^{1,2} \oplus$, Guillermo Ponce ${ }^{3}$, Johanna Troya-Balseca ${ }^{4}$, Tomás Palomo ${ }^{2,5}$ and \\ Janet Hoenicka $4,5, *$ (iD \\ 1 Departamento de Psicología, Facultad de Ciencias Biomédicas, Universidad Europea Madrid, \\ Villaviciosa de Odón, 28670 Madrid, Spain; alejandra.koeneke@gmail.com \\ 2 Departamento de Medicina Legal, Psiquiatría y Patología, Facultad de Medicina, \\ Universidad Complutense de Madrid, 28040 Madrid, Spain; tomaspalomo@med.ucm.es \\ 3 Servicio de Psiquiatría, Hospital Universitario 12 de Octubre, Av. de Córdoba s/n, 28041 Madrid, Spain; \\ gponcealfaro@gmail.com \\ 4 Laboratory of Neurogenetics and Molecular Medicine - IPER, Institut de Recerca Sant Joan de Déu, \\ 08950 Barcelona, Spain; jtroyab@gmail.com \\ 5 CIBER de Salud Mental (CIBERSAM), Instituto de Salud Carlos III, 28029 Madrid, Spain \\ * Correspondence: jhoenicka@gmail.com; Tel.: +34-936009751 (ext. 77833)
}

Received: 28 February 2020; Accepted: 2 April 2020; Published: 4 April 2020

\begin{abstract}
The TaqIA single nucleotide variant (SNV) has been tested for association with addictions in a huge number of studies. TaqIA is located in the ankyrin repeat and kinase domain containing 1 gene (ANKK1) that codes for a receptor interacting protein kinase. ANKK1 maps on the NTAD cluster along with the dopamine receptor D2 (DRD2), the tetratricopeptide repeat domain 12 (TTC12) and the neural cell adhesion molecule 1 (NCAM1) genes. The four genes have been associated with addictions, although TTC12 and ANKK1 showed the strongest associations. In silico and in vitro studies revealed that $A N K K 1$ is functionally related to the dopaminergic system, in particular with $D R D 2$. In antisocial alcoholism, epistasis between ANKK1 TaqIA and DRD2 C957T SNVs has been described. This clinical finding has been supported by the study of ANKK1 expression in peripheral blood mononuclear cells of alcoholic patients and controls. Regarding the ANKK1 protein, there is direct evidence of its location in adult and developing central nervous system. Together, these findings of the ANKK1 gene and its protein suggest that the TaqIA SNV is a marker of brain differences, both in structure and in dopaminergic function, that increase individual risk to addiction development.
\end{abstract}

Keywords: ANKK1; TaqIA; DRD2; addictions; dopamine; neurodevelopment

\section{Introduction}

Addictions are psychiatric disorders that modify the reward and learning systems of the brain [1], causing compulsive drug seeking and other maladaptive and destructive behaviors. Clinical studies have estimated that around $20 \%-40 \%$ of people who use substances of abuse will finally develop an addiction [2]. In the transition to addiction, not only the brain circuits of reward and motivation are involved, but also those of executive control and emotional processing [3]. Since gene-environment interactions underlie the functioning of brain circuits, individual differences in both genetics and environmental factors should synthesize the individual addiction vulnerability.

Family studies in twins [4] and the greater recurrence of addictions in affected families [5,6] support that the risk to develop an addiction is inherited. Addictions heritability values, which have been related to drug liability, range from $39 \%$ for hallucinogens to $72 \%$ for cocaine [7]. This heritability/liability correlation for particular drugs argues that a large component of what is inherited 
is related to individual variation in the neurobiological basis of addiction [7]. In animal models, it has been shown that the development of addictions is the result of the interaction between the degree of drug exposure and the individual vulnerable genotype [8]. As addiction develops in a small proportion of subjects, this finding also supports the genetic component of these disorders.

It has been proposed that addictions are inherited as complex diseases where a gene-environment interaction is required for their development [9]. During drug use, excessive dopamine signaling and epigenetic remodeling in the brain cause the shift to addictions [10]. In patients, a variety of environmental factors have been identified, such as early life trauma, altered family structure and social pressure. For example, it has been shown that deprivation of interactions and isolation during childhood increase the risk of developing an addiction [11,12]. On the genetic side, various loci and genes have been involved in addictions vulnerability including the gene Ankyrin repeat and kinase domain containing 1 gene (ANKK1). Specifically, the ANKK1 TaqIA single nucleotide variant (SNV) (rs1800497) is the most-studied genetic variant related to addictions [13-16]. The ANKK1 gene encodes a putative kinase that is expressed in the developing and adult central nervous system $[17,18]$. Besides, several lines of evidence link this protein with the dopaminergic system $[17,19,20]$. However, the role of the ANKK1 gene and its protein in the pathophysiology of addictions remain unknown.

In this review, we begin by presenting the actual status of the genetic association between the ANKK1 TaqIA SNV and alcoholism. As ANKK1 is located near to the gene for the dopamine D2 receptor (DRD2), we also analyze the functional relationship of $A N K K 1$ and DRD2 and have included experimental unpublished work of our laboratory that further supports this association in human peripheral blood mononuclear cells. We also proposed that $A N K K 1 / D R D 2$ relation explains, at least in part, the controversy about the TaqIA association to addictions and other dopamine-related phenotypes. In addition, here we included the genetic association studies between ANKK1 locus haplotypes and different addictions. Finally, we summarize the progress that we have made in the biology of ANKK1 in cells and animal models. As a whole, we suggest that ANKK1 protein and its variations associate to addiction vulnerability on two levels: i) during development participating in signaling pathways involved in neurogenesis and ii) during adulthood modulating the dopaminergic function in the brain.

\section{The Gene That Codes $A N K K 1$, the TaqIA SNV, and Addictions}

ANKK1 spans around 14.38 Kb (NC_000011.10) on chromosome 11. This gene comprises at least 8 exons that code for a 765 amino acid protein that would act as a serine/threonine kinase [21]. Blum et al. [13] first reported the study of the relationship between the ANKK1 TaqIA SNV and alcoholism in Caucasians. TaqIA consists of a single Cytosine (C, A2 allele) to Thymine (T, A1 allele) change in the ANKK1 gene. Since then, several groups have replicated the association between alcoholism and this genetic variant [22-30], although other authors have not found this association [31-49]. This inconsistency has been resolved by four meta-analyses including a large number of Caucasian alcoholic patients and controls. Two meta-analyses of the TaqIA confirmed an association between the A1 allele and alcoholism [50,51]. Another study of common SNVs underlying drug addiction found that TaqIA is the third most significant genetic variation associated with alcohol-related phenotypes [52]. The most recent study meta-analyzed 62 reports followed by a meta-regression to identify hidden confounders [53]. The pooled odds ratio (OR) not only estimates that the TaqIA A1 allele increases the risk of alcohol dependence but also claims that the relationship between this SNV and alcoholism, is one of the largest effects ever observed for a polymorphic genetic variant in psychiatry (OR, 1.23; $p<0.001$ ). The authors state that the association is not attributable to dopamine receptor D2 (D2R) functional differences [53].

The TaqIA A1 allele has been also associated with severe alcoholism and non-adaptive behavior [54]. Moreover, the genotype A1+ (heterozygous and homozygous for the TaqIA A1 allele) and cannabinoid genetic variants have an additive effect on the Hare Psychopathy Checklist-Revised (PCL-R) scores in severe alcoholic patients [55]. These findings suggest that there is a shared genetic liability for addictions and antisocial disorders. 
ANKK1 has also been studied in other substance use disorders $[15,56]$. For instance, there are two meta-analyses of the association between the TaqIA and smoking behavior, but with conflicting results [57,58]. The TaqIA A1 allele has also been associated with opioids addiction [59-62] and with a lower response to methadone treatment in addicted patients [59,63-65]. A recent meta-analysis shows that TaqIA was significantly associated with increased risk of opioid dependence under homozygote, dominant, and recessive genetic models (homozygote: $\mathrm{OR}=1.546,95 \% \mathrm{CI}=1.279-1.87$; dominant: $\mathrm{OR}=1.265,95 \% \mathrm{CI}=1.055-1.516$; recessive: $\mathrm{OR}=1.409,95 \% \mathrm{CI}=1.182-1.680)$ [66]. Therefore, ANKK1 TaqIA SNV is still a current genetic marker for addictive disorders.

\section{The Functional Relationship of $A N K K 1$ and DRD2}

All drugs mediate their reinforcing properties, causing a large and fast release of dopamine in limbic regions [67]. The chronic use of drugs may raise the thresholds required for dopaminergic neurons activation and dopamine signaling in response to salient stimuli. Indeed, patients with addictions have deficits in brain dopamine function in the orbitofrontal cortex, the cingulate gyrus and the dorsolateral prefrontal cortex [68]. At the same time, conditioning triggered by drugs leads to enhanced dopamine signaling in striatal and prefrontal areas when the patients are exposed to conditioned drug-associated cues. All these changes result in the loss of control and compulsive drug intake characteristic of addictions [68]. Overall, dopamine deregulation associated with drug use causes the dysfunction of the reward pathway. Therefore, dopamine is a key neurotransmitter of the pathophysiology of addictions and the genes involved in dopaminergic transmission could mediate the risk of these disorders.

Going back to the gene that encodes $A N K K 1$, we have found that this gene is linked to the dopaminergic system. In human cellular models, we showed that the ANKK1 gene and protein expression levels are affected by apomorphine (APO) [17,19], a non-selective dopaminergic agonist which acts as a partial agonist of the dopamine receptor D1-like subclass (D1R-like) and a full agonist of the dopamine receptor D2-like subclass (D2R-like). In HEK293 cells, the TaqIA SNV had a significant impact on the expression of the recombinant human ANKK1 both at basal levels and when stimulated with APO [19]. In adult mouse brain, ANKK1 mRNA expression was oppositely regulated by D1R-like and D2R-like activation [20]. Specifically, the treatment of mice with the D1R-like selective agonist SKF38393 or APO causes an Ankk1 gene up-regulation. SKF38393 binds to D1R and D5R that signal via $\mathrm{G}$ proteins through protein kinase A (PKA) and phospholipase C (PLC) pathways, respectively [69]. In contrast, treatment with the D3R agonist 7-OH-DPAT, which induces the activation of phospholipase $\mathrm{D}$ (PLD) [70], causes a strong Ankk1 downregulation. PLD regulates downstream effectors, such as protein phosphatase 1 (PP1) that controls transcriptional events that are relevant for memory formation and synaptic plasticity in the brain [71,72]. Taken together, these findings suggest that Ankk1 expression could be the result of a net effect of competing pathways of different dopamine receptors.

In silico studies revealed a tight relation between $A N K K 1$ and DRD2 genes. On the one hand, $A N K K 1$ is adjacent to the $D R D 2$ gene [21], shares haplotypic blocks and their promoters have cis elements in common for transcriptional regulation [17,73]. Additionally, TaqIA is in linkage disequilibrium with $D R D 2$ variants that regulate the expression of long and short $D 2 R$ isoforms $[73,74]$, and modulates D2R distribution in the ventral striatum [75]. TaqIA A1 allele has also been associated with increased activity of striatal L-amino acid decarboxylase, the final enzyme for dopamine synthesis [76].

The ANKK1/DRD2 locus has another SNV associated with brain dopaminergic functions that consists of a $C$ to $T$ synonymous change within exon 7 of the DRD2 gene [77]. This SNV named C957T (rs6277) has a marked impact on D2R availability [78] and it is also a marker of regulatory regions at the 5' UTR of the ANKK1 gene [73]. In a sample of alcoholic patients, we found an epistatic effect of the ANKK1 TaqIA and DRD2 C957T SNVs on the expression of antisocial traits [79]. Specifically, the risk genotypes A1+ for the ANKK1 TaqIA and CC for DRD2 C957T SNVs were associated with comorbid dissocial personality disorder and high scores on the PCL-R [79]. Moreover, there were no differences between individuals who did not carry any of the risk genotypes and those that carried 
only one of them, either A1+ for TaqIA or CC for C957T. Therefore, it seems that ANKK1 and DRD2 genes could somehow interact with the dopamine signaling pathways or act in a coordinated manner, affecting individual vulnerability to both addictions and antisocial disorder.

The ANKK1/DRD2 locus has also been related to cognitive and emotional processes $[73,80]$ that could be associated with risk for developing addictions. A recent systematic review and meta-analysis evaluated the association of ANKK1 TaqIA and DRD2 C957T SNVs in the performance of the executive functions in healthy adults [81]. Three main domains of executive functions were analyzed: response inhibition, cognitive flexibility and working memory. Regarding TaqIA, previous reports found that A1 allele carriers have been related to worse working memory performance [82-84], or with less cognitive flexibility $[82,85,86]$. However, after meta-analysis, the signification was lost [81]. C957T SNV's previous positive association with working memory function [87-89], and response inhibition $[87,88,90]$ were also negative after a meta-analysis, while cognitive flexibility was still associated. Some of these inconsistencies could be attributed to both the heterogeneity of the executive function tasks used and the variability of the populations investigated [81]. Another source of heterogeneity, which might have contributed to the lack of significant findings, could be the differences in the grouping of the genotypes between studies. While some studies compared CT vs. TT vs. CC genotypes [90], others compared CC vs. CT/TT [55]. However, given the functional relationship between ANKK1 TaqIA and DRD2 C957T $\mathrm{SNVs}$ in the dopaminergic system, the role of these genetic variants and their possible interactions upon the executive function or other cognitive processes should not be excluded.

To gain further biological insight into the functional relationship among ANKK1, DRD2 and the dopaminergic system, we have studied ANKK1 expression in human peripheral blood mononuclear cells (PBMCs) in healthy controls and detoxified alcoholic patients. PBMCs were isolated by a density gradient medium (Lymphoprep) and treated with APO, as shown in Figure 1. PBMCs express dopamine receptors and dopamine transporters and also synthesize dopamine through tyrosine hydroxylase-dependent mechanisms [91,92]. PBMCs total RNA from patients with alcoholism (n: 24) and controls (n: 17) was extracted using TRIZOL. PolyT primers were used for the RT reaction (Maxima ${ }^{\circledR}$ First Strand cDNA Synthesis Kit, Fermentas) and all quantitative real-time PCR reactions were carried out in triplicate on a 7500 Fast Real-Time PCR System (Applied Biosystems, Foster City, California, USA). RT-PCRs were performed as previously described [17].

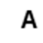

A
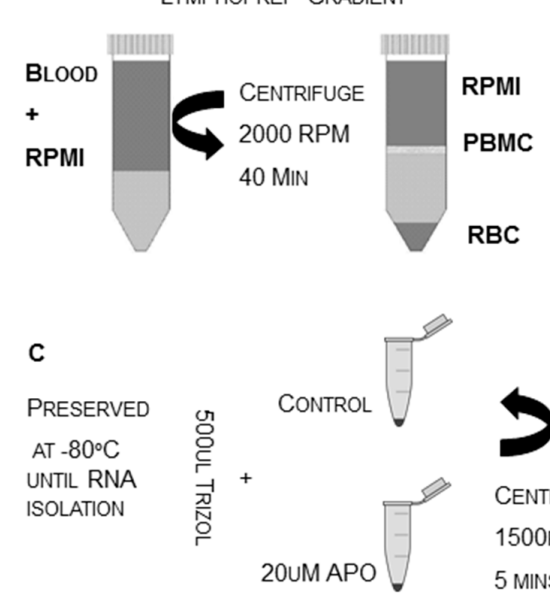

B

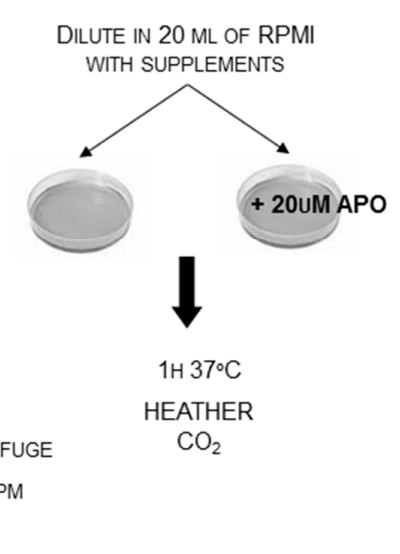

Figure 1. Protocol to obtain human peripheral blood mononuclear cells (PBMCs). (A) For each sample PBMCs were isolated in a Lymphoprep gradient, (B) diluted in $20 \mathrm{~mL}$ of RPMI and divided into two plates. One plate corresponds to basal conditions (baseline) and the other was treated with APO. (C) After the PBMCs pellets were isolated by centrifugation at $1500 \mathrm{rpm}$. RNA extraction was performed using conventional protocols. RPMI: Roswell Park Memorial Institute medium; RBC: red blood cells; APO: apomorphine. 
We evaluated $A N K K 1$ and $D R D 2$ interaction in PBMCs using a regression model including the genotypes for the two genes (ANKK1: TaqIA and DRD2: C957T) and, ANKK1 expression differences ( $\delta:$ mRNA levels after APO treatment—mRNA levels at baseline) as a quantitative dependent variable. We found a significant epistatic effect of the ANKK1 TaqIA and DRD2 C957T SNVs upon ANKK1 mRNA $\delta$ in healthy controls (F: 29.4, $p<0.0001$ ), alcoholic patients (F: 11.6, $p<0.003$ ) and the total sample (F: 35.2, $p<0.0001$ ). Figure 2 shows that the interaction of the genotype of any of the genes with the variant of the other gene has a radically different significant effect upon $A N K K 1 \delta$. In A1 + carriers, the CC genotype of $D R D 2$ is associated with a significant increase in $A N K K 1 \delta$. On the contrary, ANKK1 $\delta$ is decreased in A1-/CC genotype subgroup. Therefore, ANKK1 $\delta$ associated with the CC genotype in A1 individuals is opposite to that observed among carriers of the A1+/CC genotype.

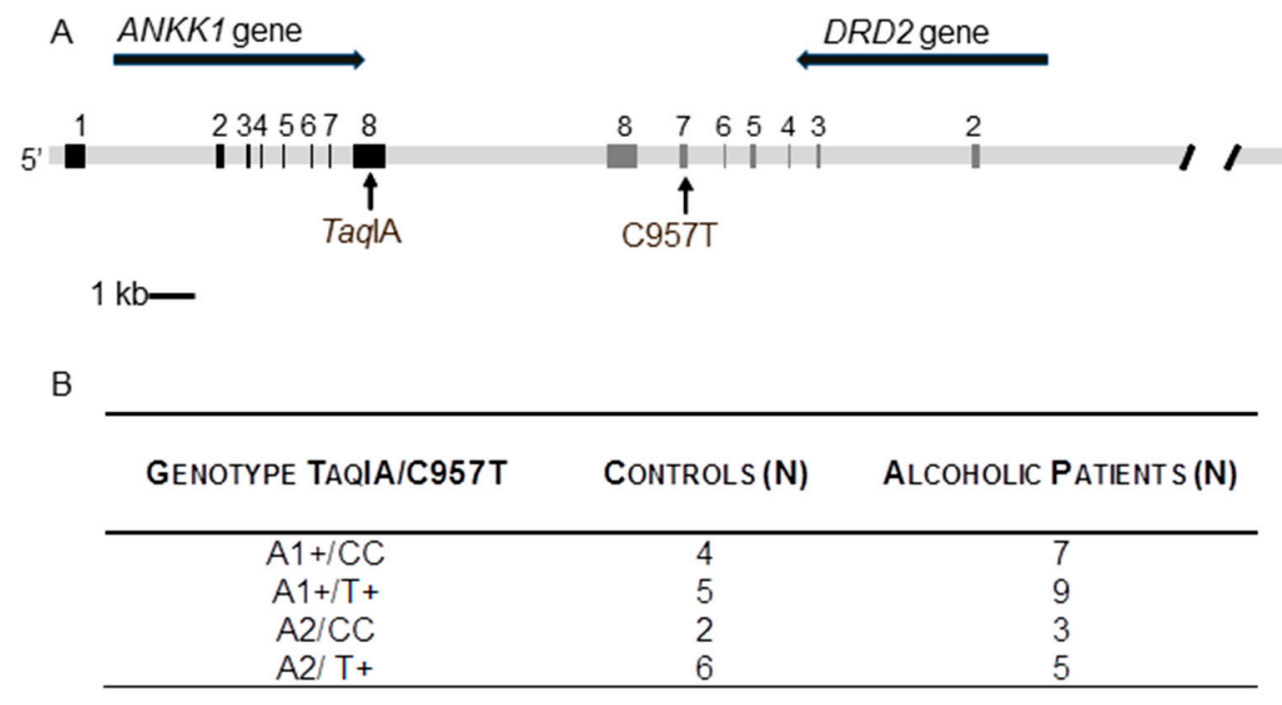

C

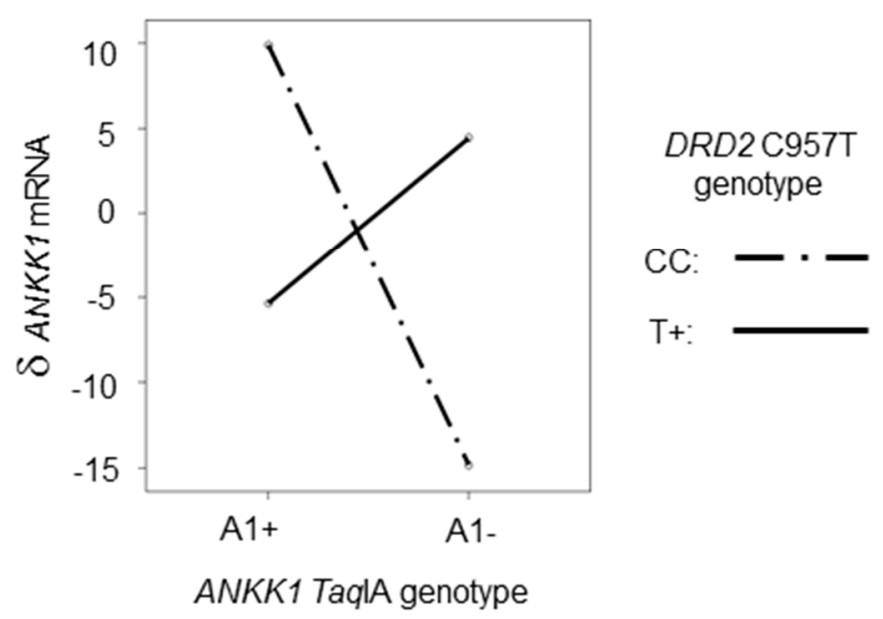

Figure 2. $A N K K 1$ and $D R D 2$ genes interaction effect on $A N K K 1$ expression levels of human PBMCs after apomorphine (APO) treatment. (A) ANKK1/DRD2 locus showing the location of ANKK1 TaqIA and DRD2 C957T SNVs. Black and grey boxes are ANKK1 and DRD2 exons, respectively. (B) ANKK1 TaqIA genotypes: A1+ (A1 allele homozygous and heterozygous) and A1- (homozygous for the A2 allele) and, DRD2 C957T genotypes: CC (C allele homozygous) and T+ (homozygous for the T allele and heterozygous) in a clinical series of alcoholic patients and control individuals. (C) $\delta$ ANKK1 mRNA: ANKK1 mRNA level differences after APO treatment. 
These findings in healthy controls and detoxified alcoholic patients not only support that ANKK1 function is closely related to dopaminergic activity, but also suggest coordination between ANKK1 and D2R. We propose that ANKK1 is involved in addictions by modulating the brain dopaminergic response at least in the dopaminergic neurons and the striatum where the D2R receptor has the highest density. Since TaqIA is tagging both $A N K K 1$ and DRD2 functional gene variants, our in vitro results in human samples represent a broader scenario to help understanding neuropsychiatric disorders associated with this SNV.

\section{The Locus of the Gene ANKK1 and Addictions}

ANKK1 gene maps to chromosome 11q22-q23 (chr11:11338038-113400418; GRCh38/hg38) in a 521-kb conserved gene cluster among vertebrates [93], along with the neural cell adhesion molecule 1 (NCAM1), DRD2 and the tetratricopeptide repeat domain 12 gene (TTC12) genes. Extensive genotyping of the NCAM-TTC12-ANKK1-DRD2 (NTAD) cluster shows that substance abuse is associated with variants of the 4 genes.

The NTAD cluster has been studied in alcoholism in family-based and case-control designs. One study found associations in exon 12-intron 13 of NCAM1, exon 3 of TTC12, and exons 2 and 5 of ANKK1 haplotypes but not with DRD2 [94]. Besides, haplotypes in TTC12 exon 3, NCAM1 exon 12, and the two 3' ends of ANKK1 and DRD2 genes, including the TaqIA SNV (the variant named A7 in this study) have been linked to comorbid alcohol and drug dependence in European-Americans [95]. Another study analyzed the involvement of DRD2 and ANKK1 in 219 Caucasian families with alcoholism, using data collected as a part of the Collaborative Study on the Genetics of Alcoholism (COGA) [96]. The strongest association was found between the subset of alcoholics with antisocial personality disorder and the ANKK1 SNV rs4938012 that is located in the 5' block of the ANKK1 gene.

The NTAD cluster has been studied in other addictions. For instance, in nicotine addiction, family-based association studies in Caucasian and African American affected sib-pairs, showed strong and consistent evidence of an association with the TTC12 (rs2303380, rs2282511) and ANKK1 (rs4938012, rs4938013, rs4938015) genes [97]. Other studies of NTAD cluster identified in the African-American and European-Americans/African-Americans pooled sample the association between the ANKK1 rs2734849 SNV and nicotine dependence [98]. Recently, a study of 268 African American daily smokers reported that primary dependence motives (PDM) are intermediate phenotypes associated to the NTAD cluster in nicotine dependence [99]. Specifically, the authors found significant associations between automaticity motives and both TTC12 (rs2282511)/ANKK1 (rs877138) and ANKK1 (rs17115439/rs4938013) haplotypes. These SNVs were also associated with automaticity in a sample of European-Americans smokers [100]. In a large male Chinese Han smokers sample (n: 2.616 patients), the study of the NTAD cluster identified two missense ANKK1 SNVs (rs11604671, rs2734849) and one intronic DRD2 SNV (rs4648317) associated with nicotine addictions [101]. The NTAD cluster has also been studied in 1459 Australian heroin-dependent cases receiving opioid replacement therapy. In this sample, evidence of an association between opioids addiction and ANKK1 (rs877138, rs4938013) and TTC12 (rs7130431) was found. This finding was replicated when comparing illicit drug-dependent and non-dependent neighborhood controls [102].

The genes that comprise the NTAD cluster show a conserved synteny and neighborhood in 22 vertebrate species using available databases [93]. In patients with addictions and healthy controls, the study of haplotypes within this cluster shows high linkage disequilibrium, haplotypes shared by several genes, and some SNVs in one gene that are also markers of another gene [73]. From a genetic perspective, these findings suggest the functional coordination of the proteins coded by genes of this cluster. Indeed, a genomic cluster is defined by a group of genes sharing genomic location and belonging to a common category, such as involvement in the same pathway or function. NCAM1 and ANKK1 have been implicated in neurogenesis $[17,18,103]$ and the ANKK1 TaqIA SNV has been associated with the morphology of the midbrain [104], the anterior cingulate cortex [105] and the caudate volume [106] in humans. Since NCAM1 and ANKK1 are expressed during development, the 
NTAD cluster association with addictions would point to inherited structural differences in brain circuits that are involved in addictions. These differences would be responsible for the risk of addictions associated with the NTAD cluster, especially with ANKK1 SNVs.

\section{ANKK1 Protein, Brain Structure, and Addiction}

To date, more than one thousand TaqIA genetic association studies in clinical samples and healthy controls have been reported in the literature, most of which assume that this polymorphism is a marker of the $D R D 2$ gene expression. However, as mentioned above, the DRD2 gene is located nearby the ANKK1 gene, which is also linked to dopaminergic function in the brain [20,76]. Therefore, there is a need to incorporate what we know today about the ANKK1 biology for a broader interpretation of the TaqIA-association genetic phenomenon. Indeed, in 2008 it had been proposed that the absence of data about ANKK1 biology is a difficulty when interpreting the link between the TaqIA and the associated phenotypes [107,108].

In 2010, our group provided the first direct evidence of ANKK1 location in adult and developing central nervous system (CNS) in astroglial cells [17]. In silico studies of ANKK1 cDNA clones and predicted peptides in Homo sapiens, Mus musculus, and Rattus norvegicus showed that there are at least 3 isoforms. The three isoforms are (i) ANKK1 full-length that includes a RIP kinase and ankyrin repeat domains ( $84 \mathrm{Kd}$ ), (ii) ANKK1-kinase with only the RIP kinase domain $(\sim 54 \mathrm{Kd})$, and (iii) ANKK1-ankyrin with only the ankyrin repeat domain ( 66 Kd) [17]. The TaqIA SNV would affect all of them. TaqIA causes the change of glutamic acid to lysine at residue 713 (E713K) in the ankyrin repeat domain [21] and it is in linkage disequilibrium with the change alanine to threonine in position 239 (A239T) in the kinase domain [19]. Since A239T could modify the kinase activity of ANKK1 [19], TaqIA is a marker of both the kinase domain and the ankyrin repeat domain of ANKK1 $[17,19]$.

Later investigations of the biology of ANKK1 unveiled that ANKK1 mRNA and protein isoforms are expressed in adult and developing CNS, not only in astroglial cells, but also in the nuclei of postmitotic neurons and neural precursors from neurogenic niches in human and mouse brain [18] (Figure 3). We also found that ANKK1 has an impact on the cell cycle that is affected by ANKK1 polymorphisms and APO treatment [18]. Additionally, the expression of ANKK1 is not restricted to the CNS, but extends to the myogenic lineage [109]. We observed ANKK1 in migrating myoblasts and satellite cells, which are muscle precursors. Thus, ANKK1 is located during development in migrating precursors of neurons and myotubes, suggesting that this protein participates in signaling pathways that control cell migration. Since NCAM1 is also expressed in neural and myogenic precursors $[103,110,111]$, ANKK1 and NCAM1 genes could play a coordinated role during development.

\section{DAPI/NeuN/ANKK1}
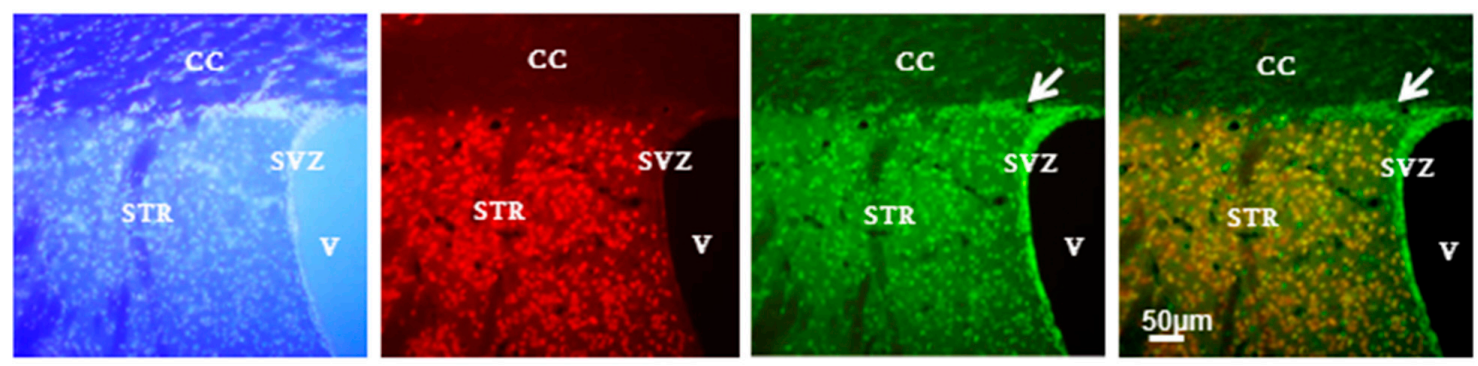

Figure 3. ANKK1 is expressed in post-mitotic neurons and also in adult neural stem cells and migrating neuroblasts of the adult mouse brain [18]. Immunostaining of ANKK1 and NeuN (marker of mature neurons) has been performed as previously described [18]. The white arrow indicates migrating neural precursors. CC: corpus callosum, STR: Striatum, SVZ: Subventricular zone, V: ventricle. Images were taken from confocal optical sections that are representative for the group averages. Scale bars: $50 \mu \mathrm{m}$. 
ANKK1, also known as RIP5, belongs to the RIP serine-threonine kinase family, which regulates and induces both intracellular inflammatory signaling pathways or, apoptotic or necrotic cell death $[112,113]$. The RIP family participates in the differentiation of a broad variety of cell types and tissues [114]: RIP2 and ANKK1 in myogenic differentiation [109,115], RIP4 (homologous to ANKK1 at both the $\mathrm{N}$-terminal kinase domain and the C-terminal ankyrin repeats) in epidermal morphogenesis during development and cutaneous wound repair [116] and, RIP7 and ANKK1 in neuronal differentiation $[17,18,117]$. Altogether, these data are in agreement for a relevant role of ANKK1 during development. Particularly, ANKK1 cell biology findings in the CNS assign a potential role for inheritance brain structure in TaqIA-associated phenotypes.

\section{Conclusion and Future Considerations}

Here, we have reviewed both the genetic evidence of the ANKK1 TaqIA SNV association with addictions and the biological evidence of the function of ANKK1.

We hypothesize that ANKK1 is involved in the pathophysiology of the TaqIA-associated phenotypes during development, participating in neurogenesis and during adulthood by modulating the dopaminergic function (Figure 4). ANKK1 SNVs may be related to subtle cytoarchitecture changes in the brain that increased the risk of developing an addiction. Moreover, since ANKK1 is linked to the dopaminergic function, it is plausible that $A N K K 1$ genetic variants also confer an additional risk in vulnerable individuals during drug use, by differences in their interaction with the DRD2 gene and with other components of the dopaminergic system. Individuals that carry ANKK1 A1+ genotype would have structural differences compared to A1- genotype [18]. These structural differences related to TaqIA would cause increased dopamine biosynthesis [76] in the dopaminergic neurons of the ventral tegmental area (VTA), which results in higher tonic dopamine firing. Tonic dopamine stimulates D2R-like inhibitory signaling pathways in medium spiny neurons (MSN) of the striatum. Prior to drug use, high levels of dopamine in the brain have been linked to both increased impulsive reward-seeking and dopamine responsivity, which may be risk factors for addiction development [118] (Figure 4A). When consumption of a drug occurs, phasic dopamine neuronal firing stimulates both adenyl cyclase (AC) at the D1R and PLC-beta at the D5R or D1R-like/D2R-like hetero-oligomers, raising the levels of cyclic AMP (cAMP) or calcium, respectively. The dopamine- and cAMP-regulated phosphoprotein, Mr 32,000 (DARPP-32) plays a central role in integrating cAMP and calcium signaling in MSNs. The increase in intracellular calcium results in DARPP-32 dephosphorylation and nuclear PP1 activity [119], which would control ANKK1 expression (Figure 4B). The carriers of ANKK1 A1+ genotype with higher tonic levels of dopamine may also have differences in phasic dopamine firing that could contribute to the transition from drug use to the emergence of an addictive disorder.

More research is needed to decipher ANKK1 biology and its participation in the vulnerability to addictions. The development of animal models to study ANKK1 and their in-depth phenotype will help to understand the underlying biology of the TaqIA genetic association with so many phenotypes. It is also likely that multiple pathophysiological mechanisms may contribute to the association of this well-studied SNV. Further investigation of ANKK1 biology, in cellular and animal models, will provide actionable biological insight about the pathophysiology and future therapies of addictions. 


\section{A. Vulnerability in TaqIA A1+ carriers}

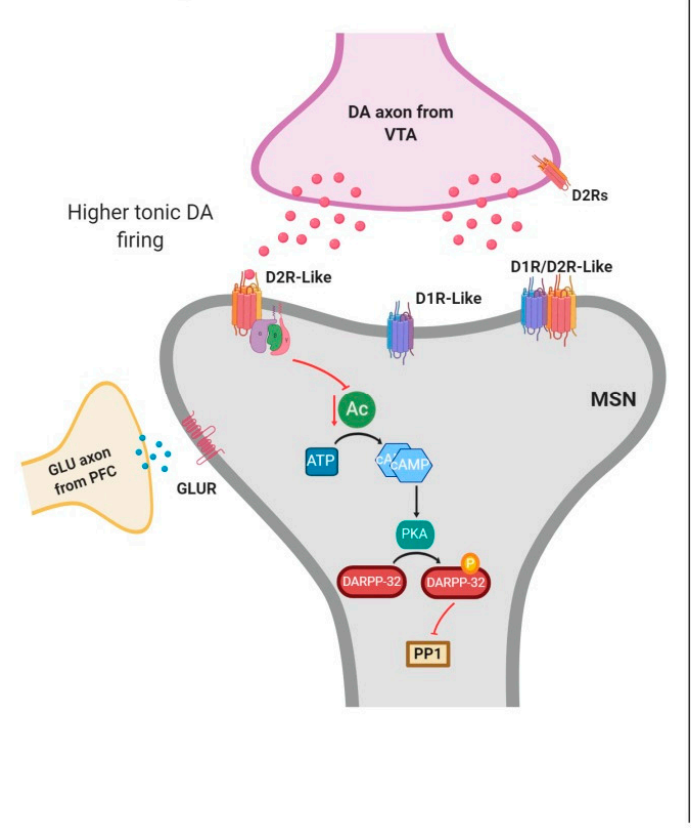

\section{B. Drug consumption}

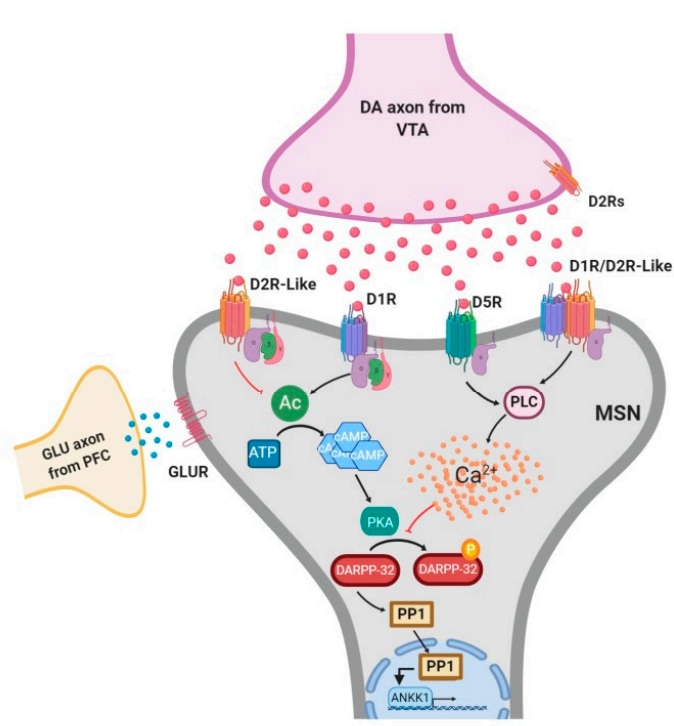

Figure 4. Proposed model for the relationship of ANKK1, the dopaminergic system in the mesolimbic brain and addiction. (A). The vulnerability of ANKK1 A1+ genotype carriers and tonic dopamine firing, (B). Drug consumption, phasic DA firing and ANKK1 expression. DA: dopamine (rose dots); VTA: ventral tegmental area; D2R: DA receptor D2; MSN medium spiny neurons; AC: adenyl cyclase; D1R: DA receptor 1; PLC: Phospholipase C beta; D5R: DA receptor 5; D1R-like/D2R -like: DA hetero-oligomers; cAMP: cyclic AMP; $\mathrm{Ca}^{2+}$ : calcium (yellow dots); DARPP-32: DA- and cAMP-regulated phosphoprotein, Mr 32,000; PP1: protein phosphatase 1 GLUR: glutamatergic receptor. Created with BioRender.

Author Contributions: A.K., G.P. and J.H. have contributed in the data acquisition and analysis. A.K., G.P., T.P. and $\mathrm{JH}$ have contributed in the experimental design. T.P. and J.H. have contributed in the conception and funding. A.K., G.P., J.T.-B., T.P. and J.H. have contributed in writing the original draft of the manuscript. All authors have done a critical review of the manuscript. All authors have read and agreed to the published version of the manuscript.

Funding: This research was supported by the Fondo de Investigación Sanitaria, Instituto Salud Carlos III, Grants PI015/01013 (JH) and PI019/00126 (JH), Spain. The CIBERSAM is an initiative of the Instituto de Salud Carlos III.

Acknowledgments: We very much appreciate Noelia Guerra Martín-Palanco and Irene González Guede for their technical assistance. Ethics Approval: The study has been approved by the Clinical Research Ethics Committee of "Institut de Recerca Sant Joan de Déu", Barcelona (PIC-93-16).

Conflicts of Interest: The authors declare no conflict of interest.

\section{References}

1. Koob, G.F.; Volkow, N.D. Neurocircuitry of addiction. Neuropsychopharmacology 2010, 35, 217-238. [CrossRef] [PubMed]

2. Egervari, G.; Ciccocioppo, R.; Jentsch, J.D.; Hurd, Y.L. Shaping vulnerability to addiction-The contribution of behavior, neural circuits and molecular mechanisms. Neurosci. Biobehav. Rev. 2018, 85, 117-125. [CrossRef] [PubMed]

3. Volkow, N.D.; Boyle, M. Neuroscience of Addiction: Relevance to Prevention and Treatment. Am. J. Psychiatry 2018, 175, 729-740. [CrossRef] [PubMed]

4. Bevilacqua, L.; Goldman, D. Genes and Addictions. Clin. Pharmacol. Ther. 2009, 85, 359-361. [CrossRef] [PubMed]

5. Kendler, K.S.; Davis, C.; Kessler, R.C. The familial aggregation of common psychiatric and substance use disorders in the National Comorbidity Survey: A family history study. Br. J. Psychiatry 1997, 170, 541-548. [CrossRef] 
6. Merikangas, K.R.; Stolar, M.; Stevens, D.E.; Goulet, J.; Preisig, M.A.; Fenton, B.; Zhang, H.; O'Malley, S.S.; Rounsaville, B.J. Familial transmission of substance use disorders. Arch. Gen. Psychiatry 1998, 55, 973-979. [CrossRef]

7. Goldman, D.; Oroszi, G.; Ducci, F. The genetics of addictions: Uncovering the genes. Nat. Rev. Genet. 2005, 6, 521-532. [CrossRef]

8. Deroche-Gamonet, V.; Belin, D.; Piazza, P.V. Evidence for Addiction-like Behavior in the Rat. Science 2004, 305, 1014-1017. [CrossRef]

9. Merikangas, K.R.; Avenevoli, S. Implications of genetic epidemiology for the prevention of substance use disorders. Addict. Behav. 2000, 25, 807-820. [CrossRef]

10. Nestler, E.J.; Lüscher, C. The Molecular Basis of Drug Addiction: Linking Epigenetic to Synaptic and Circuit Mechanisms. Neuron 2019, 102, 48-59. [CrossRef]

11. Baarendse, P.J.J.; Limpens, J.H.W.; Vanderschuren, L.J.M.J. Disrupted social development enhances the motivation for cocaine in rats. Psychopharmacology (Berl) 2014, 231, 1695-1704. [CrossRef] [PubMed]

12. Wong, W.C.; Ford, K.A.; Pagels, N.E.; McCutcheon, J.E.; Marinelli, M. Adolescents are more vulnerable to cocaine addiction: Behavioral and electrophysiological evidence. J. Neurosci. 2013, 33, 4913-4922. [CrossRef]

13. Blum, K.; Noble, E.P.; Sheridan, P.J.; Montgomery, A.; Ritchie, T.; Jagadeeswaran, P.; Nogami, H.; Briggs, A.H.; Cohn, J.B. Allelic association of human dopamine D2 receptor gene in alcoholism. JAMA 1990, 263, 2055-2060. [CrossRef]

14. Noble, E.P. D2 dopamine receptor gene in psychiatric and neurologic disorders and its phenotypes. Am. J. Med. Genet. Part B Neuropsychiatr. Genet. 2003, 116, 103-125. [CrossRef] [PubMed]

15. Ponce, G.; Perez-Gonzalez, R.; Aragüés, M.; Palomo, T.; Rodríguez-Jiménez, R.; Jimenez-Arriero, M.A.; Hoenicka, J. The ANKK1 Kinase Gene and Psychiatric Disorders. Neurotox. Res. 2009, 16, 50-59. [CrossRef] [PubMed]

16. Wang, F.; Simen, A.; Arias, A.; Lu, Q.-W.; Zhang, H. A large-scale meta-analysis of the association between the ANKK1/DRD2 Taq1A polymorphism and alcohol dependence. Hum. Genet. 2012, 132, 347-358. [CrossRef] [PubMed]

17. Hoenicka, J.; Lombraña, A.Q.; España-Serrano, L.; Alvira, X.; Kremer, L.; Perez-Gonzalez, R.; Rodríguez-Jiménez, R.; Jimenez-Arriero, M.A.; Ponce, G.; Palomo, T. The ANKK1 Gene Associated with Addictions Is Expressed in Astroglial Cells and Upregulated by Apomorphine. Boil. Psychiatry 2010, 67, 3-11. [CrossRef] [PubMed]

18. España-Serrano, L.; Martín-Palanco, N.G.; Montero-Pedrazuela, A.; Perez-Santamarina, E.; Vidal, R.; García-Consuegra, I.; Valdizan, E.; Pazos, A.; Palomo, T.; Jiménez-Arriero, M.; et al. The Addiction-Related Protein ANKK1 is Differentially Expressed During the Cell Cycle in Neural Precursors. Cereb. Cortex 2017, 27, 2809-2819. [CrossRef]

19. Garrido, E.; Palomo, T.; Ponce, G.; Garcia-Consuegra, I.; Jiménez-Arriero, M.A.; Hoenicka, J. The ANKK1 protein associated with addictions has nuclear and cytoplasmic localization and shows a differential response of Ala239Thr to apomorphine. Neurotox. Res. 2011, 20, 32-39. [CrossRef]

20. Ponce, G.; Lombraña, A.Q.; Martín-Palanco, N.G.; Rubio-Solsona, E.; Jimenez-Arriero, M.A.; Palomo, T.; Hoenicka, J. The Addiction-Related Gene Ankk1 is Oppositely Regulated by D1R- and D2R-Like Dopamine Receptors. Neurotox. Res. 2016, 29, 345-350. [CrossRef]

21. Neville, M.J.; Johnstone, E.C.; Walton, R.T. Identification and characterization of ANKK1: A novel kinase gene closely linked to DRD2 on chromosome band 11q23.1. Hum. Mutat. 2004, 23, 540-545. [CrossRef] [PubMed]

22. Blum, K.; Noble, E.P.; Sheridan, P.J.; Finley, O.; Montgomery, A.; Ritchie, T.; Ozkaragoz, T.; Fitch, R.J.; Sadlack, F.; Sheffield, D.; et al. Association of the A1 allele of the D2 dopamine receptor gene with severe alcoholism. Alcohol 1991, 8, 409-416. [CrossRef]

23. Comings, D.E.; Muhleman, D.; Dietz, G.; Shahbahrami, B.; Tast, D.; Knell, E.; Kocsis, P.; Baumgarten, R.; Kovacs, B.W.; Levy, D.L.; et al. The Dopamine D2 Receptor Locus as a Modifying Gene in Neuropsychiatric Disorders. JAMA 1991, 266, 1793-1800. [CrossRef] [PubMed]

24. Parsian, A.; Todd, R.D.; Devor, E.J.; O’Malley, K.L.; Suarez, B.K.; Reich, T.; Cloninger, C.R. Alcoholism and alleles of the human D2 dopamine receptor locus. Studies of association and linkage. Arch. Gen. Psychiatry 1991, 48, 655-663. [CrossRef] [PubMed] 
25. Blum, K.; Noble, E.P. Alcoholism and the D2 Dopamine Receptor Gene. JAMA 1993, 270, 1547-1548. [CrossRef]

26. Neiswanger, K.; Hill, S.Y.; Kaplan, B.B. Association and linkage studies of the TAQI A1 allele at the dopamine D2 receptor gene in samples of female and male alcoholics. Am. J. Med. Genet. 1995, 60, 267-271. [CrossRef] [PubMed]

27. Hietala, J.; Pohjalainen, T.; Heikkilä-Kallio, U.; West, C.; Salaspuro, M.; Syvälahti, E. Allelic association between D2 but not D1 dopamine receptor gene and alcoholism in Finland. Psychiatr. Genet. 1997, 7, 19-25. [CrossRef]

28. Kono, Y.; Yoneda, H.; Sakai, T.; Nonomura, Y.; Inayama, Y.; Koh, J.; Sakai, J.; Inada, Y.; Imamichi, H.; Asaba, H. Association between early-onset alcoholism and the dopamine D2 receptor gene. Am. J. Med. Genet. 1997, 74, 179-182. [CrossRef]

29. Ishiguro, H.; Arinami, T.; Saito, T.; Akazawa, S.; Enomoto, M.; Mitushio, H.; Fujishiro, H.; Tada, K.; Akimoto, Y.; Mifune, H.; et al. Association study between the -141C Ins/Del and TaqI A polymorphisms of the dopamine D2 receptor gene and alcoholism. Alcohol. Clin. Exp. Res. 1998, 22, 845-848. [CrossRef]

30. Foley, P.F.; Loh, E.W.; Innes, D.J.; Williams, S.M.; Tannenberg, A.E.G.; Harper, C.G.; Dodd, P.R. Association Studies of Neurotransmitter Gene Polymorphisms in Alcoholic Caucasians. Ann. N. Y. Acad. Sci. 2004, 1025, 39-46. [CrossRef]

31. Bolos, A.M.; Dean, M.; Lucas-Derse, S.; Ramsburg, M.; Brown, G.L.; Goldman, D. Population and Pedigree Studies Reveal a Lack of Association Between the Dopamine D2 Receptor Gene and Alcoholism. JAMA 1991, 264, 3156-3160. [CrossRef]

32. Gelernter, J.; O’Malley, S.; Risch, N.; Kranzler, H.R.; Krystal, J.; Merikangas, K.; Kennedy, J.L.; Kidd, K.K. No association between an allele at the D2 dopamine receptor gene (DRD2) and alcoholism. JAMA 1991, 266, 1801-1807. [CrossRef] [PubMed]

33. Turner, E.; Ewing, J.; Shilling, P.; Smith, T.L.; Irwin, M.R.; Schuckit, M.; Kelsoe, J.R. Lack of association between an RFLP near the D2 dopamine receptor gene and severe alcoholism. Boil. Psychiatry 1992, 31, 285-290. [CrossRef]

34. Goldman, D.; Dean, M.; Brown, G.L.; Bolos, A.M.; Tokola, R.; Virkkunen, M.; Linnoila, M. D2dopamine receptor genotype and cerebrospinal fluid homovanillic acid, 5-hydroxyindoleacetic acid and 3-methoxy-4-hydroxyphenylglycol in alcoholics in Finland and the United States. Acta Psychiatr. Scand. 1992, 86, 351-357. [CrossRef]

35. Arinami, T.; Itokawa, M.; Komiyama, T.; Mitsushio, H.; Mori, H.; Mifune, H.; Hamaguchi, H.; Toru, M. Association between severity of alcoholism and the A1 allele of the dopamine D2 receptor gene TaqI A RFLP in Japanese. Boil. Psychiatry 1993, 33, 108-114. [CrossRef]

36. Goldman, D.; Urbanek, M.; Guenther, D.; Robin, R.; Long, J.C. Linkage and association of a functional DRD2 variant [Ser311Cys] and DRD2 markers to alcoholism, substance abuse and schizophrenia in Southwestern American Indians. Am. J. Med. Genet. 1997, 74, 386-394. [CrossRef]

37. Suarez, B.; Parsian, A.; Hampe, C.; Todd, R.; Reich, T.; Cloninger, C. Linkage Disequilibria at the D2 Dopamine Receptor Locus (DRD2) in Alcoholics and Controls. Genomics 1994, 19, 12-20. [CrossRef]

38. Cruz, C.; Camarena, B.; Mejía, J.M.; Páez, F.; Eroza, V.; De La Fuente, J.R.; Kershenobich, D.; Nicolini, H. The dopamine D2 receptor gene TaqI A1 polymorphism and alcoholism in a Mexican population. Arch. Med. Res. $1995,26,421-426$.

39. Sander, T.; Harms, H.; Podschus, J.; Finckh, U.; Nickel, B.; Rolfs, A.; Rommelspacher, H.; Schmidt, L.G. Dopamine D1, D2 and D3 receptor genes in alcohol dependence. Psychiatr. Genet. 1995, 5, 171-176. [CrossRef]

40. Sander, T.; Ladehoff, M.; Samochowiec, J.; Finckh, U.; Rommelspacher, H.; Schmidt, L.G. Lack of an allelic association between polymorphisms of the dopamine D2 receptor gene and alcohol dependence in the German population. Alcohol. Clin. Exp. Res. 1999, 23, 578-581. [CrossRef]

41. Lu, R.-B.; Ko, H.-C.; Chang, F.-M.; Castiglione, C.M.; Schoolfield, G.; Pakstis, A.J.; Kidd, J.R.; Kidd, K.K. No association between alcoholism and multiple polymorphisms at the dopamine D2 receptor gene (DRD2) in three distinct taiwanese populations. Boil. Psychiatry 1996, 39, 419-429. [CrossRef]

42. Chen, C.; Chien, S.; Hwu, H.-G. Lack of association between TaqI A1 allele of dopamine D2 receptor gene and alcohol-use disorders in Atayal natives of Taiwan. Am. J. Med. Genet. 1996, 67, 488-490. [CrossRef]

43. Chen, W.; Lu, M.L.; Hsu, Y.P.; Chen, C.C.; Yu, J.M.; Cheng, A.T. Dopamine D2 receptor gene and alcoholism among four aboriginal groups and Han in Taiwan. Am. J. Med. Genet. 1997, 74, 129-136. [CrossRef] 
44. Edenberg, H.J.; Foroud, T.; Koller, D.L.; Goate, A.; Rice, J.; Van Eerdewegh, P.; Reich, T.; Cloninger, C.R.; Nurnberger, J.I.; Kowalczuk, M.; et al. A family-based analysis of the association of the dopamine D2 receptor (DRD2) with alcoholism. Alcohol. Clin. Exp. Res. 1998, 22, 505-512. [CrossRef]

45. Lobos, E.A.; Todd, R.D. Association analysis in an evolutionary context: Cladistic analysis of the DRD2 locus to test for association with alcoholism. Am. J. Med. Genet. 1998, 81, 411-419. [CrossRef]

46. Gelernter, J. D2 Dopamine Receptor Gene (DRD2) Allele and Haplotype Frequencies in Alcohol Dependent and Control Subjects No Association with Phenotype or Severity of Phenotype. Neuropsychopharmacology 1999, 20, 640-649. [CrossRef]

47. Lee, J.-F.; Lu, R.-B.; Ko, H.-C.; Chang, F.-M.; Yin, S.-J.; Pakstis, A.J.; Kidd, K. No Association Between DRD2 Locus and Alcoholism After Controlling the ADH and ALDH Genotypes in Chinese Han Population. Alcohol. Clin. Exp. Res. 1999, 23, 592-599. [CrossRef]

48. Waldman, I.D.; Robinson, B.F.; Rhee, S.H. A logistic regression extension of the transmission disequilibrium test for continuous traits: Application to linkage disequilibrium between alcoholism and the candidate genes DRD2 and ADH3. Genet. Epidemiol. 1999, 17, S379-S384. [CrossRef]

49. Parsian, A.; Cloninger, C.R.; Zhang, Z.H. Functional variant in the DRD2 receptor promoter region and subtypes of alcoholism. Am. J. Med. Genet. 2000, 96, 407-411. [CrossRef]

50. Munafò, M.R.; Matheson, I.J.; Flint, J.; Munaf, I.J.M.M.R. Association of the DRD2 gene Taq1A polymorphism and alcoholism: A meta-analysis of case-control studies and evidence of publication bias. Mol. Psychiatry 2007, 12, 454-461. [CrossRef]

51. Smith, L.; Watson, M.; Gates, S.; Ball, D.; Foxcroft, D. Meta-Analysis of the Association of the Taq1A Polymorphism with the Risk of Alcohol Dependency: A HuGE Gene-Disease Association Review. Am. J. Epidemiol. 2008, 167, 125-138. [CrossRef] [PubMed]

52. Bühler, K.-M.; Giné, E.; Echeverry-Alzate, V.; Calleja-Conde, J.; De Fonseca, F.R.; Moreno, J.A.L. Common single nucleotide variants underlying drug addiction: More than a decade of research. Addict. Boil. 2015, 20, 845-871. [CrossRef] [PubMed]

53. Jung, Y.; Montel, R.A.; Shen, P.-H.; Mash, D.C.; Goldman, D. Assessment of the Association of D2 Dopamine Receptor Gene and Reported Allele Frequencies with Alcohol Use Disorders: A Systematic Review and Meta-analysis. JAMA Netw. Open 2019, 2, e1914940. [CrossRef] [PubMed]

54. Ponce, G.; Jimenez-Arriero, M.A.; Rubio, G.; Hoenicka, J.; Ampuero, I.; Ramos, J.A.; Palomo, T. The A1 allele of the DRD2 gene (TaqI A polymorphisms) is associated with antisocial personality in a sample of alcohol-dependent patients. Eur. Psychiatry 2003, 18, 356-360. [CrossRef] [PubMed]

55. Rodríguez-Jiménez, R.; Hoenicka, J.; Jiménez-Arriero, M.; Ponce, G.; Bagney, A.; Aragues, M.; Palomo, T. Performance in the Wisconsin Card Sorting Test and the C957T Polymorphism of the DRD2 Gene in Healthy Volunteers. Neuropsychobiology 2006, 54, 166-170. [CrossRef]

56. Uhl, G.; Blum, K.; Noble, E.; Smith, S. Substance abuse vulnerability and D2 receptor genes. Trends Neurosci. 1993, 16, 83-88. [CrossRef]

57. Li, M.D.; Ma, J.; Beuten, J. Progress in searching for susceptibility loci and genes for smoking-related behaviour. Clin. Genet. 2004, 66, 382-392. [CrossRef]

58. Munafò, M.R.; Clark, T.G.; Johnstone, E.C.; Murphy, M.F.G.; Walton, R.T. The genetic basis for smoking behavior: A systematic review and meta-analysis. Nicotine Tob. Res. 2004, 6, 583-597. [CrossRef]

59. Lawford, B.R.; Young, R.M.; Noble, E.P.; Sargent, J.; Rowell, J.; Shadforth, S.; Zhang, X.; Ritchie, T. The $\mathrm{D}(2)$ dopamine receptor $\mathrm{A}(1)$ allele and opioid dependence: Association with heroin use and response to methadone treatment. Am. J. Med. Genet. 2000, 96, 592-598. [CrossRef]

60. Cobos, J.P.D.L.; Baiget, M.; Trujols, J.; Sinol, N.; Volpini, V.; Banuls, E.; Calafell, F.; Luquero, E.; Del Rio, E.; Álvarez, E. Allelic and genotypic associations of DRD2 TaqI A polymorphism with heroin dependence in Spanish subjects: A case control study. Behav. Brain Funct. 2007, 3, 25. [CrossRef]

61. Hou, Q.-F.; Li, S.-B. Potential association of DRD2 and DAT1 genetic variation with heroin dependence. Neurosci. Lett. 2009, 464, 127-130. [CrossRef] [PubMed]

62. Vereczkei, A.; Demetrovics, Z.; Szekely, A.; Sárközy, P.; Antal, P.; Szilágyi, Á.; Sasvári-Székely, M.; Barta, C. Multivariate Analysis of Dopaminergic Gene Variants as Risk Factors of Heroin Dependence. PLoS ONE 2013, 8, e66592. [CrossRef] [PubMed] 
63. Barratt, D.; Coller, J.K.; Somogyi, A.A. Association between theDRD2 A1 allele and response to methadone and buprenorphine maintenance treatments. Am. J. Med. Genet. Part B Neuropsychiatr. Genet. 2006, 141, 323-331. [CrossRef] [PubMed]

64. Crettol, S.; Besson, J.; Croquette-Krokar, M.; Hämmig, R.; Gothuey, I.; Monnat, M.; Deglon, J.-J.; Preisig, M.; Eap, C.B. Association of dopamine and opioid receptor genetic polymorphisms with response to methadone maintenance treatment. Prog. Neuro-Psychopharmacol. Boil. Psychiatry 2008, 32, 1722-1727. [CrossRef]

65. Doehring, A.; Von Hentig, N.; Graff, J.; Salamat, S.; Schmidt, M.; Geisslinger, G.; Harder, S.; Lötsch, J. Genetic variants altering dopamine D2 receptor expression or function modulate the risk of opiate addiction and the dosage requirements of methadone substitution. Pharmacogenetics Genom. 2009, 19, 407-414. [CrossRef] [PubMed]

66. Deng, X.D.; Jiang, H.; Ma, Y.; Gao, Q.; Zhang, B.; Mu, B.; Zhang, L.-X.; Zhang, W.; Er, Z.-E.M.; Xie, Y.; et al. Association between DRD2/ANKK1 TaqIA polymorphism and common illicit drug dependence: Evidence from a meta-analysis. Hum. Immunol. 2015, 76, 42-51. [CrossRef]

67. Chiara, G.; Imperato, A. Preferential Stimulation of Dopamine Release in the Nucleus Accumbens by Opiates, Alcohol, and Barbiturates: Studies with Transcerebral Dialysis in Freely Moving Rats. Ann. N. Y. Acad. Sci. 1986, 473, 367-381. [CrossRef]

68. Volkow, N.D.; Fowler, J.S.; Wang, G.-J.; Telang, F.; Baler, R. Imaging Dopamine's Role in Drug Abuse and Addiction. Neuropharmacology 2009, 56, 3-8. [CrossRef]

69. Sahu, A.; Tyeryar, K.R.; Vongtau, H.O.; Sibley, D.R.; Undieh, A. D5 dopamine receptors are required for dopaminergic activation of phospholipase C. Mol. Pharmacol. 2009, 75, 447-453. [CrossRef]

70. Everett, P.B.; Senogles, S.E. D3dopamine receptor signals to activation of phospholipase D through a complex with Rho. J. Neurochem. 2010, 112, 963-971. [CrossRef] [PubMed]

71. Koshibu, K.; Gräff, J.; Beullens, M.; Heitz, F.D.; Berchtold, D.; Russig, H.; Farinelli, M.; Bollen, M.; Mansuy, I.M. Protein Phosphatase 1 Regulates the Histone Code for Long-Term Memory. J. Neurosci. 2009, 29, 13079-13089. [CrossRef] [PubMed]

72. Gräff, J.; Koshibu, K.; Jouvenceau, A.; Dutar, P.; Mansuy, I.M. Protein phosphatase 1-dependent transcriptional programs for long-term memory and plasticity. Learn. Mem. 2010, 17, 355-363. [CrossRef] [PubMed]

73. Koeneke, A.; Ponce, G.; Hoenicka, J.; Huertas, E. The ANKK1/DRD2 locus is a genomic substrate for affective priming and recognition of angry faces. Brain Behav. 2015, 5, e00405. [CrossRef] [PubMed]

74. Zhang, Y.; Bertolino, A.; Fazio, L.; Blasi, G.; Rampino, A.; Romano, R.; Lee, M.-L.T.; Xiao, T.; Papp, A.; Wang, D.; et al. Polymorphisms in human dopamine D2 receptor gene affect gene expression, splicing, and neuronal activity during working memory. Proc. Natl. Acad. Sci. USA 2007, 104, 20552-20557. [CrossRef] [PubMed]

75. Valli, M.; Cho, S.S.; Masellis, M.; Chen, R.; Rusjan, P.; Kim, J.; Koshimori, Y.; Mihaescu, A.; Strafella, A.P. DRD2 Genotype-Based Variants Modulates D2 Receptor Distribution in Ventral Striatum. Mol. Neurobiol. 2019, 56, 6512-6520. [CrossRef] [PubMed]

76. Laakso, A.; Pohjalainen, T.; Bergman, J.; Kajander, J.; Haaparanta, M.; Solin, O.; Syvälahti, E.; Hietala, J. The A1 allele of the human D2 dopamine receptor gene is associated with increased activity of striatal L-amino acid decarboxylase in healthy subjects. Pharmacogenetics Genom. 2005, 15, 387-391. [CrossRef]

77. Duan, J.; Wainwright, M.S.; Comeron, J.M.; Saitou, N.; Sanders, A.R.; Gelernter, J.; Gejman, P.V. Synonymous mutations in the human dopamine receptor D2 (DRD2) affect mRNA stability and synthesis of the receptor. Hum. Mol. Genet. 2003, 12, 205-216. [CrossRef]

78. Hirvonen, M.; Laakso, A.; Någren, K.; Rinne, J.; Pohjalainen, T.; Hietala, J. C957T polymorphism of the dopamine D2 receptor (DRD2) gene affects striatal DRD2 availability in vivo. Mol. Psychiatry 2004, 9, 1060-1061. [CrossRef]

79. Ponce, G.; Hoenicka, J.; Jiménez-Arriero, M.A.; Rodríguez-Jiménez, R.; Aragües, M.; Martin-Sune, N.; Huertas, E.; Palomo, T. DRD2 and ANKK1 genotype in alcohol-dependent patients with psychopathic traits: Association and interaction study. Br. J. Psychiatry 2008, 193, 121-125. [CrossRef]

80. Huertas, E.; Ponce, G.; Koeneke, M.A.; Poch, C.; Palomo, T.; Hoenicka, J.; España-Serrano, L.; Jiménez-Arriero, M.Á. The D2 dopamine receptor gene variant C957T affects human fear conditioning and aversive priming. Genes Brain Behav. 2010, 9, 103-109. [CrossRef] 
81. Klaus, K.; Butler, K.; Curtis, F.; Bridle, C.; Pennington, K. The effect of ANKK1 Taq1A and DRD2 C957T polymorphisms on executive function: A systematic review and meta-analysis. Neurosci. Biobehav. Rev. 2019, 100, 224-236. [CrossRef] [PubMed]

82. Ariza, M.; Garolera, M.; Jurado, M.A.; Garcia-Garcia, I.; Hernan, I.; Sánchez-Garre, C.; Vernet-Vernet, M.; Sender-Palacios, M.J.; Marques-Iturria, I.; Pueyo, R.; et al. Dopamine genes (DRD2/ANKK1-TaqA1 and DRD4-7R) and executive function: Their interaction with obesity. PLoS ONE 2012, 7, e41482. [CrossRef] [PubMed]

83. Butcher, P.A. Cortical-Subcortical Interactions in Cognitive Control, Associative Learning and Motor Control. Ph.D. Thesis, University of California, Berkeley, CA, USA, 2014.

84. Berryhill, M.E.; Wiener, M.; Stephens, J.A.; Lohoff, F.W.; Coslett, H.B. COMT and ANKK1-Taq-Ia Genetic Polymorphisms Influence Visual Working Memory. PLoS ONE 2013, 8, e55862. [CrossRef] [PubMed]

85. Stelzel, C.; Basten, U.; Montag, C.; Reuter, M.; Fiebach, C. Frontostriatal Involvement in Task Switching Depends on Genetic Differences in D2 Receptor Density. J. Neurosci. 2010, 30, 14205-14212. [CrossRef]

86. Nkam, I.; Ramoz, N.; Breton, F.; Mallet, J.; Gorwood, P.; Dubertret, C. Impact of DRD2/ANKK1 and COMT Polymorphisms on Attention and Cognitive Functions in Schizophrenia. PLoS ONE 2017, 12, e0170147. [CrossRef]

87. Bellander, M.; Bäckman, L.; Liu, T.; Schjeide, B.-M.M.; Bertram, L.; Schmiedek, F.; Lindenberger, U.; Lövdén, M. Lower baseline performance but greater plasticity of working memory for carriers of the val allele of the COMT Val(1)(5)(8)Met polymorphism. Neuropsychology 2015, 29, 247-254. [CrossRef]

88. Colzato, L.S.; Steenbergen, L.; Sellaro, R.; Stock, A.-K.; Arning, L.; Beste, C. Effects of 1-Tyrosine on working memory and inhibitory control are determined by DRD2 genotypes: A randomized controlled trial. Cortex 2016, 82, 217-224. [CrossRef]

89. Klaus, K.; Butler, K.; Durrant, S.J.; Ali, M.; Inglehearn, C.F.; Hodgson, T.L.; Gutierrez, H.; Pennington, K. The effect of COMT Val158Met and DRD2 C957T polymorphisms on executive function and the impact of early life stress. Brain Behav. 2017, 7, e00695. [CrossRef]

90. Gurvich, C.; Rossell, S.L. Genetic variations in dopamine and inhibitory control: Lack of influence on action restraint. Behav. Brain Res. 2014, 267, 12-16. [CrossRef]

91. Ferrari, M.; Cosentino, M.; Marino, F.; Bombelli, R.; Rasini, E.; Lecchini, S.; Frigo, G. Dopaminergic D1-like receptor-dependent inhibition of tyrosine hydroxylase mRNA expression and catecholamine production in human lymphocytes. Biochem. Pharmacol. 2004, 67, 865-873. [CrossRef]

92. Ahangari, G.; Shariati, G.H.; Asadi, M.R.; Ostadali, M.R.; Ahmadkhaniha, H.R. Novel Mutation Detection of Regulatory Molecule Dopamine Gene Receptors (D1-D5) Encoding Analysis on Human Peripheral Blood Lymphocytes in Schizophrenia Patients. Eur. J. Inflamm. 2009, 7, 145-152. [CrossRef]

93. Mota, N.R.; Araujo-Jnr, E.V.; Paixão-Côrtes, V.R.; Bortolini, M.C.; Bau, C.H.D. Linking dopamine neurotransmission and neurogenesis: The evolutionary history of the NTAD (NCAM1-TTC12-ANKK1-DRD2) gene cluster. Genet. Mol. Boil. 2012, 35 (Suppl. 4), 912-918. [CrossRef] [PubMed]

94. Yang, B.-Z.; Kranzler, H.R.; Zhao, H.; Gruen, J.; Luo, X.; Gelernter, J. Association of haplotypic variants in DRD2, ANKK1, TTC12 and NCAM1 to alcohol dependence in independent case-control and family samples. Hum. Mol. Genet. 2007, 16, 2844-2853. [CrossRef] [PubMed]

95. Yang, B.-Z.; Kranzler, H.R.; Zhao, H.; Gruen, J.R.; Luo, X.; Gelernter, J. Haplotypic variants in DRD2, ANKK1, TTC12, and NCAM1 are associated with comorbid alcohol and drug dependence. Alcohol. Clin. Exp. Res. 2008, 32, 2117-2127. [CrossRef] [PubMed]

96. Dick, D.; Wang, J.C.; Plunkett, J.; Aliev, F.; Hinrichs, A.; Bertelsen, S.; Budde, J.; Goldstein, E.L.; Kaplan, D.; Edenberg, H.J.; et al. Family-Based Association Analyses of Alcohol Dependence Phenotypes Across DRD2 and Neighboring Gene ANKK1. Alcohol. Clin. Exp. Res. 2007, 31, 1645-1653. [CrossRef] [PubMed]

97. Gelernter, J.; Yu, Y.; Weiss, R.; Brady, K.; Panhuysen, C.; Yang, B.-Z.; Kranzler, H.R.; Farrer, L.A. Haplotype spanning TTC12 and ANKK1, flanked by the DRD2 and NCAM1 loci, is strongly associated to nicotine dependence in two distinct American populations. Hum. Mol. Genet. 2006, 15, 3498-3507. [CrossRef] [PubMed]

98. Huang, W.; Payne, T.; Ma, J.Z.; Beuten, J.; Dupont, R.T.; Inohara, N.; Li, M.D. Significant Association of ANKK1 and Detection of a Functional Polymorphism with Nicotine Dependence in an African-American Sample. Neuropsychopharmacology 2009, 34, 319-330. [CrossRef]

99. Bidwell, L.C.; McGeary, J.E.; Gray, J.C.; Palmer, R.; Knopik, V.S.; MacKillop, J. NCAM1-TTC12-ANKK1-DRD2 variants and smoking motives as intermediate phenotypes for nicotine dependence. Psychopharmacology (Berl) 2015, 232, 1177-1186. [CrossRef] 
100. Bidwell, L.C.; McGeary, J.E.; Gray, J.C.; Palmer, R.; Knopik, V.; MacKillop, J. An initial investigation of associations between dopamine-linked genetic variation and smoking motives in African Americans. Pharmacol. Biochem. Behav. 2015, 138, 104-110. [CrossRef]

101. Liu, Q.; Xu, Y.; Mao, Y.; Ma, Y.; Wang, M.; Han, H.; Cui, W.; Yuan, W.; Payne, T.J.; Xu, Y.; et al. Genetic and Epigenetic Analysis Revealing Variants in the NCAM1-TTC12-ANKK1-DRD2 Cluster Associated Significantly with Nicotine Dependence in Chinese Han Smokers. Nicotine Tob. Res. 2019. [CrossRef]

102. Nelson, E.C.; Lynskey, M.T.; Heath, A.C.; Wray, N.R.; Agrawal, A.; Shand, F.L.; Henders, A.; Wallace, L.; Todorov, A.A.; Schrage, A.J.; et al. ANKK1, TTC12, and NCAM1 polymorphisms and heroin dependence: Importance of considering drug exposure. JAMA Psychiatry 2013, 70, 325-333. [CrossRef] [PubMed]

103. Bonfanti, L. PSA-NCAM in mammalian structural plasticity and neurogenesis. Prog. Neurobiol. 2006, 80, 129-164. [CrossRef] [PubMed]

104. Cerasa, A.; Gioia, M.C.; Tarantino, P.; Labate, A.; Arabia, G.; Annesi, G.; Lanza, P.; Di Palma, G.; Blasi, V.; Quattrone, A. The DRD2 TaqIA polymorphism associated with changed midbrain volumes in healthy individuals. Genes Brain Behav. 2009, 8, 459-463. [CrossRef] [PubMed]

105. Montag, C.; Weber, B.; Jentgens, E.; Elger, C.; Reuter, M. An epistasis effect of functional variants on the $\mathrm{BDNF}$ and DRD2 genes modulates gray matter volume of the anterior cingulate cortex in healthy humans. Neuropsychologia 2010, 48, 1016-1021. [CrossRef] [PubMed]

106. Li, X.; Papenberg, G.; Bäckman, L.; Persson, J. Influence of the DRD2/ANKK1 Taq1A polymorphism on caudate volume in older adults without dementia. Brain Struct. Funct. 2018, 223, 2653-2662. [CrossRef]

107. Klein, T.A.; Neumann, J.; Reuter, M.; Hennig, J.; Von Cramon, D.Y.; Ullsperger, M. Genetically Determined Differences in Learning from Errors. Science 2007, 318, 1642-1645. [CrossRef] [PubMed]

108. Lucht, M.; Rosskopf, D. Comment on "Genetically Determined Differences in Learning from Errors". Science 2008, 321, 200. [CrossRef]

109. Rubio-Solsona, E.; Martí, S.; Vílchez, J.J.; Palau, F.; Hoenicka, J. ANKK1 is found in myogenic precursors and muscle fibers subtypes with glycolytic metabolism. PLOS ONE 2018, 13, e0197254.

110. Cashman, N.R.; Covault, J.; Wollman, R.L.; Sanes, J.R. Neural cell adhesion molecule in normal, denervated, and myopathic human muscle. Ann. Neurol. 1987, 21, 481-489. [CrossRef]

111. Capkovic, K.L.; Stevenson, S.; Johnson, M.C.; Thelen, J.J.; Cornelison, D. Neural cell adhesion molecule (NCAM) marks adult myogenic cells committed to differentiation. Exp. Cell Res. 2008, 314, 1553-1565. [CrossRef]

112. Witt, A.; Vucic, D. Diverse ubiquitin linkages regulate RIP kinases-mediated inflammatory and cell death signaling. Cell Death Differ. 2017, 24, 1160-1171. [CrossRef] [PubMed]

113. Zhang, D.; Lin, J.; Han, J. Receptor-interacting protein (RIP) kinase family. Cell. Mol. Immunol. 2010, 7, 243-249. [CrossRef] [PubMed]

114. Meylan, E.; Tschopp, J. The RIP kinases: Crucial integrators of cellular stress. Trends Biochem. Sci. 2005, 30, 151-159. [CrossRef] [PubMed]

115. Munz, B.; Hildt, E.; Springer, M.L.; Blau, H.M. RIP2, a Checkpoint in Myogenic Differentiation. Mol. Cell. Biol. 2002, 22, 5879-5886. [CrossRef]

116. Adams, S.; Munz, B. RIP4 is a target of multiple signal transduction pathways in keratinocytes: Implications for epidermal differentiation and cutaneous wound repair. Exp. Cell Res. 2010, 316, 126-137. [CrossRef]

117. Bahnassawy, L.; Nicklas, S.; Palm, T.; Menzl, I.; Birzele, F.; Gillardon, F.; Schwamborn, J.C. The Parkinson's Disease-Associated LRRK2 Mutation R1441G Inhibits Neuronal Differentiation of Neural Stem Cells. Stem Cells Dev. 2013, 22, 2487-2496. [CrossRef]

118. Leyton, M.; Vezina, P. Dopamine ups and downs in vulnerability to addictions: A neurodevelopmental model. Trends Pharmacol. Sci. 2014, 35, 268-276. [CrossRef]

119. Nishi, A.; Bibb, J.A.; Matsuyama, S.; Hamada, M.; Higashi, H.; Nairn, A.C.; Greengard, P. Regulation of DARPP-32 dephosphorylation at PKA- and Cdk5-sites by NMDA and AMPA receptors: Distinct roles of calcineurin and protein phosphatase-2A. J. Neurochem. 2002, 81, 832-841. [CrossRef]

(C) 2020 by the authors. Licensee MDPI, Basel, Switzerland. This article is an open access article distributed under the terms and conditions of the Creative Commons Attribution (CC BY) license (http://creativecommons.org/licenses/by/4.0/). 